\title{
Role of two contrasting ecosystem engineers (Zostera noltii and Cymodocea nodosa) on the food intake rate of Cerastoderma edule
}

\author{
Fernando G. Brun · Elleke van Zetten · Eva Cacabelos • \\ Tjeerd J. Bouma
}

Received: 4 October 2007 / Revised: 2 April 2008 / Accepted: 19 April 2008 / Published online: 4 November 2008 (C) The Author(s) 2008. This article is published with open access at Springerlink.com

\begin{abstract}
Seagrasses are well known ecosystem engineers that can significantly influence local hydrodynamics and the abundance and biodiversity of macrobenthic organisms. This study focuses on the potential role of the seagrass canopy structure in altering the abundance of filterfeeding organisms by modifying the hydrodynamic driven food supply. We quantified the effect of two ecosystem engineers with contrasting canopy properties (i.e. Zostera noltii and Cymodocea nodosa) on the food intake rate of a suspension-feeding bivalve Cerastoderma edule living in these seagrass meadows. Field experiments were carried out in two seagrass beds (Z. noltii and C. nodosa) and bare sediment, located on sandflat characterised by a relatively high hydrodynamic energy from waves and currents. Results demonstrated that the filter-feeding rate was almost twofold increased when $C$. edule was inhabiting $Z$. noltii meadows $\left(1.10 \pm 0.24 \mu \mathrm{g}\right.$ Chl g Fresh Weight $\left.{ }^{-1}\right)$ when compared to cockles living on the bare sediment $(0.65 \pm$ $\left.0.14 \mu \mathrm{g} \mathrm{Chl} \mathrm{g} \mathrm{FW}^{-1}\right)$. Intermediate values were found within $C$. nodosa canopy $\left(0.97 \pm 0.24 \mu \mathrm{g} \mathrm{Chl} \mathrm{g} \mathrm{FW}^{-1}\right)$, but filter feeding rate showed no significant differences with values for $Z$. noltii meadows. There were no apparent correlations between canopy properties and filter-feeding rates. Our results imply that food refreshment within the seagrass canopies was enough to avoid food depletion. We therefore expect that the ameliorated environmental conditions within vegetated areas (i.e. lower hydrodynamic conditions,
\end{abstract}

Communicated by K. Reise.

F. G. Brun $(\bowtie) \cdot$ E. van Zetten · E. Cacabelos · T. J. Bouma

Centre for Estuarine and Marine Ecology,

Netherlands Institute of Ecology (NIOO-KNAW),

Yerseke, The Netherlands

e-mail: fernando.brun@uca.es higher sediment stability, lower predation pressure...) in combination with sufficient food supply to prevent depletion within both canopies are the main factors underlying our observations.

Keywords Ecosystem engineers · Seagrasses · Biodiversity $\cdot$ Filter feeding rate $\cdot$ Cockles abundance . Habitat modification

\section{Introduction}

Over the past decades there has been a growing interest on seagrass-dominated areas as indicated by a rapidly increasing number of studies (e.g. Duarte 1999; see references therein Larkum et al. 2006a). This has resulted in a much better knowledge of biological and ecological processes, spanning from the individual to the whole ecosystem level (Larkum et al. 2006b). From these studies, it has become clear that seagrasses are highly valuable ecosystems that provide several important ecosystem services (Costanza et al. 1997). Many of these ecosystem services are related to the ecosystem engineering (sensu Jones et al. 1994) characteristics of seagrasses, which are known to be able to strongly ameliorate hydrodynamic conditions within their meadows (e.g. see Abdelrhman 2003; Bouma et al. 2005; Koch 2001; Verduin and Backhaus 2000 and references therein).

One of the most important ecosystem services of seagrass beds is the support of a high biodiversity of invertebrates and fishes (Heck et al. 1997; Beck et al. 2001; Heck et al. 2003), some of them with a high economical value (e.g. blue crab; Pile et al. 1996). These biodiversity effects have been ascribed to a number of different possible indirect mechanisms: (1) altered plant-animal interactions 
(settlement of new recruitments; Eckman 1983; Boström and Bonsdorff 2000), (2) changes on the intensity of biological interactions (mainly predation-prey interactions; Nelson and Bonsdorff 1990; Irlandi and Peterson 1991), (3) decrease on the flow (Fonseca et al. 1982; Gambi et al. 1990) causing (3a) an increase on the sediment stability (Fonseca and Fisher 1986; Irlandi 1996) and (3b) alterations on the food supply to the organisms (Irlandi and Peterson 1991; Allen and Williams 2003). Especially the latter mechanisms are closely related to the ecosystem engineering ability of seagrasses, and raise some intriguing questions with respect to filter feeding macrobenthic animals that live in seagrass meadows.

Filter feeders normally benefit from strong hydrodynamics that cause a higher refreshment rate of the food and a higher horizontal and vertical transport of particles on the water column (Fréchette and Bourget 1985; Emerson 1990). Hence, a reduced water movement typical for inside seagrass canopies (Gambi et al. 1990) would be expected to reduce food availability and consequently the growth of filter-feeding organisms. However, a careful analysis of literature reveals rather contrasting results. Whereas some studies demonstrated that the growth rate and/or survival of filter feeder organism living within seagrass beds are lower than those occurring in non-vegetated areas (Reusch and Williams 1999, Allen and Williams 2003), others concluded that these organisms obtain benefits living inside vegetations (Irlandi and Peterson 1991; Irlandi 1996; Peterson and Heck 2001). Food availability within seagrass canopy was acknowledged as a main factor responsible of such observations in both negative (Allen and Williams 2003) and positive (Irlandi and Peterson 1991) interactions.

The extent to which hydrodynamic energy within a meadow (and thus the food supply to filter feeders) is modified, is largely dependent on the canopy characteristics of the seagrass meadow (e.g. density, stiffness, length, etc....; see Bouma et al. 2005 and Koch and Gust 1999 and references therein). Hence, we speculate that contrasting results between studies on the growth and/or survival of filter feeder in seagrass meadows might perhaps be partly explained by contrasting seagrass canopy properties by having different effects on food supply. In order to elucidate the effect of canopy properties on the food supply to filter feeding organisms inhabiting vegetated areas, we compared the food uptake of Cerastoderma edule in two seagrass species with contrasting canopy properties (Zostera noltii Horneman vs. Cymodocea nodosa (Ucria) Ascherson) and in the non-vegetated surroundings. Previous studies demonstrated that differences in canopy properties (shoots density, height and stiffness) caused the water flux through the canopy of $C$. nodosa to be approximately double of that through a Z. noltii canopy (Morris et al. 2008). Therefore, we hypothesised that (a) both seagrass species will decrease the food intake rate of $C$. edule compared to non-vegetated areas and, (b) that the filtration rate will be the lowest for cockles inhabiting Z. noltii beds. Our hypotheses were tested by measuring the chlorophyll content of starved cockles after $24 \mathrm{~h}$ feeding within a $Z$. noltii meadow, a $C$. nodosa meadow, or in the non-vegetated surroundings. Chlorophyll content was used as proxy for the food intake rate of the cockles, which is the resultant of the combination of food availability and filter-feeding rate (Hummel 1985; Kamermans 1993).

\section{Materials and methods}

\section{Field site characterisation}

Our study was conducted in an intertidal sandflat at Los Toruños (el Bajo de la Cabezuela), a salt marsh ecosystem of $773 \mathrm{Ha}$ situated in the Cadiz Bay Natural Park (Southern Spain, latitude $36^{\circ} 31^{\prime} 35.37^{\prime \prime}$ N, longitude $\left.6^{\circ} 14^{\prime} 4.15^{\prime \prime} \mathrm{W}\right)$. This sandflat, located at the mouth of a tidal channel, undergoes strong tidal currents, waves and winds with recurrent episodes of sediment erosion and accretion (see Brun et al. 2005 for further information and Kagan et al. 2005 for a detailed physical description of the location). Mean velocity module measured $10 \mathrm{~cm}$ above the sea floor during a tidal cycle showed a velocity range from 5 to $30 \mathrm{~cm} \mathrm{~s}^{-1}$ (Lara M. personal communication) while wave heights varies from $0 \mathrm{~cm}$ on calm days to $15-20 \mathrm{~cm}$ on windy days (Kagan et al. 2005). This sandflat is colonized by patches of the seagrass $Z$. noltii Hornem. in the intertidal areas, whereas more continuous beds of $Z$. noltii and Cymodocea nodosa (Ucria) Ascherson thrive in the lower intertidal and shallow subtidal zones. In the study site, Z. noltii develops in denser stands but with a shorter canopy height compared to C. nodosa (see Brun et al. 2006 for further details).

To determine the background chlorophyll $a$ concentrations in the water column, at some of the days, water samples were taken by collecting the water at $50 \mathrm{~cm}$ depth some metres far away from the main leading edge of the meadow. This was done in triplicate per day, and repeated three times over the experimental period. In the lab, the water samples were filtered $(1 \mathrm{l}$; whatman $\mathrm{GF} / \mathrm{C})$ at low pressure and analysed after soaking the filter for $24 \mathrm{~h}$ on acetone (kept in cold and darkness; $90 \%$ buffered acetone). Chlorophyll $a$ concentration (including phaeophytin) was subsequently measured using a Turner fluorometer according the methods described by Strickland and Parsons (1968). Data are expressed as $\mu \mathrm{g} \mathrm{Chl} a 1^{-1}$. The average chlorophyll $a$ concentration in the water samples was found to be $0.65 \pm 0.73 \mu \mathrm{g} \mathrm{Chl} a 1^{-1}(n=3)$. 


\section{C. edule sampling and preparation}

Adult specimens of Cerastoderma edule were collected from bare sediment, $500 \mathrm{~m}$ upstream from the experimental location and transported within the next hour to the laboratory. For all experimental days and treatments, the cockles had an average size of $24.56 \pm 2.42 \mathrm{~mm}$ and an average fresh weight of $1.78 \pm 0.54 \mathrm{~g} \mathrm{FW}^{-1}(n=336)$. To starve the animals, all cockles were kept for $24 \mathrm{~h}$ in five aquaria with 401 natural seawater, which was continuously bubbled with air. After this starvation period, 30 cockles per treatments (4-5 plots per treatment; in total 360-450 cockles) were selected and allocated in a non-labelled bag and transported to the field. Another ten starved cockles were frozen to estimate the initial values of chlorophyll content on the individuals. This basal value was subtracted every day from the experimental cockles to assess the food intake rate. This procedure was repeated every sampling day.

Experimental plot selection and carrying out the experiment

Mono-specific stands of $Z$. noltii and $C$. nodosa were selected in the shallow subtidal $(15-20 \mathrm{~cm}$ water depth on low tide) of the study site. The experimental plots were selected taking into account several conditionals. First, the seagrass meadows had to exceed a radius of at least 10 metres. Second, the three treatment plots (bare sediment, $Z$. noltii and $C$. nodosa meadows) had to be relatively near to each other in order to obtain comparable hydrodynamic conditions. Third, the place to put the cockles were selected to not contain natural populations of cockles and to be far away from the leading edge of the meadow (i.e. usually in the midpoint of the meadow) to avoid any enhanced mixing due to leading edge effects (e.g. see Irlandi and Peterson 1991; Gambi et al. 1990; Folkard 2005; Bouma et al. 2007).

Every sampling day (see below), four to five plots within each treatment (bare sediment, Z. noltii and C. nodosa meadows) were selected and marked with small wooden sticks during low tide. In these experimental plots $(0.25 \times 0.25 \mathrm{~m})$, the starved $C$. edule individuals were haphazardly distributed on the top of the sediment, reaching a final density of 480 cockles $\mathrm{m}^{-2}$, which was in good agreement with natural cockle densities in the area where cockles were previously collected (F.G. Brun unpublished data). After a tidal cycle ( $24 \mathrm{~h}$ ) cockles and seagrasses were recollected from the experimental plots by extracting the sediment to $20 \mathrm{~cm}$ depth, sieved in the field and transported in cool boxes with ice till laboratory (less than $1 \mathrm{~h}$ ). Once in the laboratory, cockles were frozen $\left(-20^{\circ} \mathrm{C}\right)$ and analysed on the following days (see C. edule analysis below). Seagrass samples were analysed on the same day (see seagrass analysis below).
The whole experimental procedure was repeated five times during June-July corresponding with the lowest tides occurring in the morning (experiments started between 9:00 and 10:00 am).

Chlorophyll analysis in C. edule analysis

The foot and body part of the frozen $C$. edule individuals were cut away from the shell and weighed. Anteroposterior axis of the shell was also measured. The chlorophyll content of the tissues was analysed spectrophotometrically after grinding and extracting it overnight in acetone $(3 \mathrm{ml}$, buffered acetone 90\%). Equations by Jeffrey et al. (1997) were used to determine the concentration of chlorophyll $a$ and $b$ of the extracts. Initial data from the starved cockles were also measured every sampling day and this value was subtracted from the experimental values (cockles after $24 \mathrm{~h}$ on the field). Data are expressed as $\mu \mathrm{g} \mathrm{Chl} \mathrm{g} \mathrm{FW}^{-1}$.

\section{Characterisation of the seagrass meadows}

Seagrass material collected together with the cockles was split into above and below-ground tissues. The number of shoots in the experimental plots was measured and abovebelow-ground biomass weighed after $48 \mathrm{~h}$ in an oven $\left(60^{\circ} \mathrm{C}\right)$. Above-ground and below-ground biomasses were expressed as g Dry Weight $\mathrm{m}^{-2}$. Sub-samples (20 shoots per plot) were used to measure the number of leaves per shoot and the length and width of individual leaves. Leaf length was measured with a ruler (accuracy $1.0 \mathrm{~mm}$ ), while leaf width was measured with a calliper (accuracy $0.01 \mathrm{~mm}$ ). Leaf area index (i.e. LAI; expressed as $\mathrm{m}^{2}$ leaf $/ \mathrm{m}^{-2}$ sediment surface) was calculated by considering just one side of the leaf.

\section{Statistical analysis}

Differences between treatments were tested by using two factors blocked ANOVA design. The levels of variability were the sampling days $(n=5)$ and the experimental plots $(n=63)$. This statistical design where plots are considered as the experimental units is more conservative than other possible alternatives as for instance, treating individual cockles within plots as independent replicates. Differences on canopy properties between both seagrass species were analysed by a one-way ANOVA. Multiple correlations were conducted between seagrass canopy properties and the recorded food intake rate of the cockles. Normality of the data and homogeneity of variances were previously tested (Zar 1984) and data were log transformed when necessary. Multiple post hoc comparisons between means were assessed by the Tukey test procedure (Zar 1984). Level of significance $(\alpha)$ was set at 0.05 . Data are presented as mean \pm SD. 


\section{Results}

In all the experimental plots, we were able to re-collect more than $95 \%$ of all Cerastoderma edule individuals, indicating that there are no differences in the survival rate between days and experimental plots during these 24-h experiments (Table 1). Chlorophyll content on the cockles after $24 \mathrm{~h}$ of feeding (proxy for food intake rate), showed a great dependence on the treatments (bare sediment, Z. noltii and Cymodocea nodosa meadows; Table 1 and Fig. 1). That is, chlorophyll content (after subtracting initial values from starved cockles, Fig. 1 showed data without subtracting) increased almost twofold from those cockles occurring at the bare sediment $\left(0.65 \pm 0.14 \mu \mathrm{g} \mathrm{Chl} \mathrm{g} \mathrm{FW}^{-1}\right)$ to those cockles

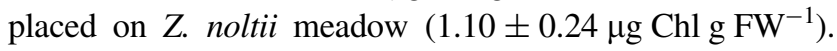
Cockles from $C$. nodosa stands showed intermediate values

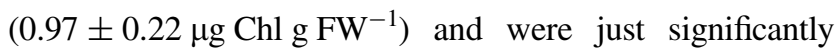
different from those cockles thriving on bare sediment (Fig. 1). Sampling day had no effect on chlorophyll content, and there were also no interactions between sampling day and treatments (Table 1).

As was expected, most of the characteristics measured in both seagrass species showed significant differences (Tables 2, 3). Cymodocea nodosa rendered the longest and widest leaves compared to Z. noltii (Table 3), while shoot density was four times higher for $Z$. noltii $(1,072 \pm 239$ and $3,842 \pm 838$ shoots $\mathrm{m}^{-2}$ for $C$. nodosa and Z. noltii). However, neither above-ground biomass nor LAI was statistically different between species (Tables 2, 3). Although multiple correlation between seagrass canopy properties and chlorophyll content on $C$. edule individuals were conducted, the food intake rate of cockles did not correlate

Table 1 Statistical results of the two factors blocked ANOVA design examining the effect of treatments (bare sediment, Zostera noltii and Cymodocea nodosa meadows) on the chlorophyll content (proxy for food intake rate) and survival rate of Cerastoderma edule from the oneway ANOVA test examining the differences on biological properties between both seagrass species

\begin{tabular}{lrrrl}
\hline Source of variation & DF & SS & $F$ & $p$ \\
\hline Chlorophyll content & & & & \\
Treatment & 2 & 2.24 & 7.35 & $\mathbf{0 . 0 0 1 7}$ \\
Days & 4 & 0.17 & 0.28 & 0.887 \\
Treatment $\times$ days & 8 & 0.35 & 0.29 & 0.967 \\
Error & 48 & 7.32 & & \\
Survival rate & & & & \\
Treatment & 2 & 1.31 & 0.22 & 0.81 \\
Days & 4 & 6.72 & 0.57 & 0.68 \\
Treatment $\times$ days & 8 & 5.76 & 0.25 & 0.98 \\
Error & 48 & 176.0 & & \\
\hline Signifcance lev $(\alpha)$ & & & & \\
\hline
\end{tabular}

Significance level $(\alpha)$ was set at 0.05 of probability

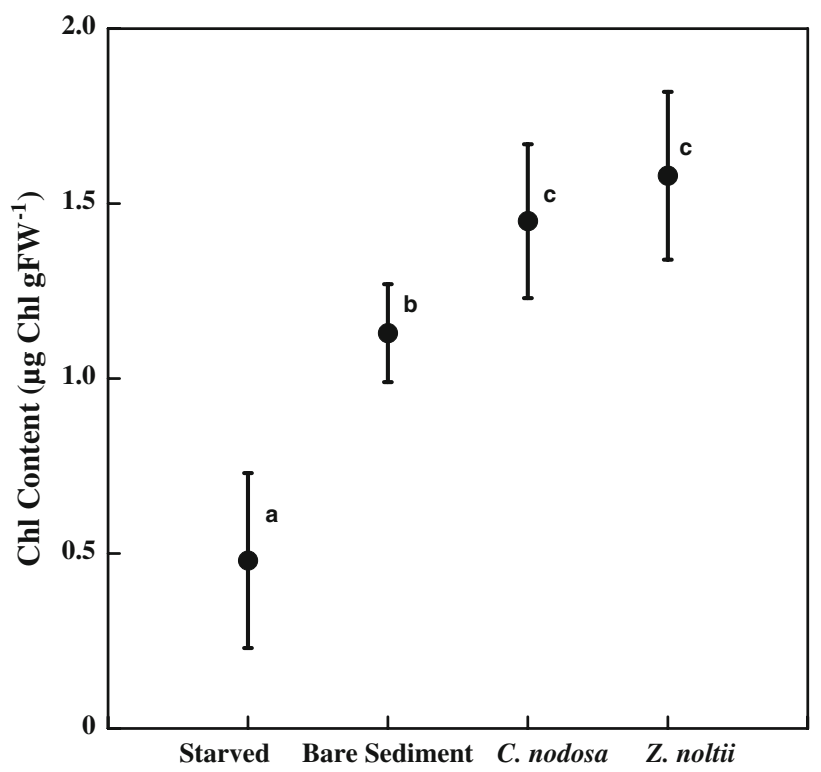

Fig. 1 Effects of two seagrass species in the chlorophyll content (resembling the food intake) of Cerastoderma edule assayed under field conditions. Data are presented as mean $\pm \operatorname{SD}(n=21)$. Different letters indicate significant differences between treatments determined by post hoc Tuckey's test. See "Statistical analysis" section for further details on statistical procedure. Note that in the plotted data the chlorophyll content of the starved cockles has not been subtracted from the experimental data, while this was done in the data showed in the "Results" section

significantly with shoot morphometry (leaf length or width; data not shown), shoot density ( $r=0.27, p=0.06, n=42)$, above biomass $(r=0.28, p=0.07, n=42)$ or leaf area index (i.e. LAI; $r=0.11, p=0.47, n=42$ ) (Fig. 2a-c).

\section{Discussion}

To our knowledge, this is the first study to quantify the effect of two ecosystem engineering seagrass species with strongly contrasting canopy properties on the food intake rate of an active suspension feeder. In contrast, previous studies focussed on patch size and energy regime (Irlandi 1996), bentic infaunal recruitment (Boström and Bonsdorff 2000), density manipulation of seagrasses (Irlandi and Peterson 1991) and/or bivalves (Reusch And Williams 1998; Peterson and Heck 2001) and food availability (Allen and Williams 2003). Our results clearly demonstrate for both seagrass species Cymodocea nodosa and Z. noltii that Cerastoderma edule living within seagrass beds in a zone with a relatively high hydrodynamic energy, is able to increase the food intake rate relative to that in non-vegetated areas. No significant differences were found between both seagrass species, despite that earlier studies indicated that their contrasting canopy properties caused a factor two difference in canopy fluxes (Morris et al. 2008). 
Table 2 Statistical results of the one-way ANOVA test examining the differences on biological properties between both seagrass species

\begin{tabular}{lllcc}
\hline Source of variation & DF & SS & $F$ & $p$ \\
\hline Seagrass properties & & & & \\
Above-ground biomass & 1 & 2386 & 0.81 & 0.373 \\
Below-ground biomass & 1 & 216464 & 40.60 & $<\mathbf{0 . 0 0 0 1}$ \\
Shoot density & 1 & 789540406 & 80.63 & $<\mathbf{0 . 0 0 0 1}$ \\
LAI & 1 & 0.07 & 0.07 & 0.789 \\
Leaf length & 1 & 2208 & 81.4 & $<\mathbf{0 . 0 0 0 1}$ \\
Leaf width & 1 & 62.63 & 421.9 & $\mathbf{< 0 . 0 0 0 1}$ \\
Leaf per shoot & 1 & 4.47 & 20.57 & $\mathbf{< 0 . 0 0 0 1}$ \\
\hline
\end{tabular}

Significance level $(\alpha)$ was set at 0.05 of probability

Table 3 Zostera noltii and Cymodocea nodosa canopy and population characteristics

\begin{tabular}{lrrr}
\hline Seagrass characteristics & $\begin{array}{l}\text { Zostera } \\
\text { noltii }\end{array}$ & $\begin{array}{l}\text { Cymodocea } \\
\text { nodosa }\end{array}$ & $n$ \\
\hline $\begin{array}{l}\text { Above-ground } \\
\quad \text { Biomass (g DW m }\end{array}$ & $134.4 \pm 30$ & $117.3 \pm 26$ & 21 \\
Below-ground & $183 \pm 40^{\mathrm{b}}$ & $38.9 \pm 9^{\mathrm{a}}$ & 21 \\
$\quad$ Biomass (g DW m & \\
Shoot density (shoots m & & \\
LAI $\left(\mathrm{m}^{2} \mathrm{~m}^{-2}\right)$ & $3,842 \pm 838^{\mathrm{b}}$ & $1,072 \pm 240^{\mathrm{a}}$ & 21 \\
Leaf length $(\mathrm{cm})$ & $2.19 \pm 0.48$ & $2.31 \pm 0.52$ & 21 \\
Leaf width (mm) & $15.4 \pm 3.4^{\mathrm{b}}$ & $29.8 \pm 6.7^{\mathrm{a}}$ & 21 \\
Leaf per shoot & $1.38 \pm 0.3^{\mathrm{b}}$ & $3.80 \pm 0.9^{\mathrm{a}}$ & 21 \\
\hline
\end{tabular}

Data are expressed as average \pm SD. Different letters indicate differences between species derived from the one-way ANOVA analysis

To our surprise, both our hypotheses were rejected. Our findings were however quite robust, as the field experiment was run five different times over a 2-month period. Hence, our results should integrate both for temporal variability in environmental conditions (e.g. hydrodynamics, food availability) plus the physiological status of the C. edule individuals, and for spatial variability in canopy properties. Furthermore, statistical design was conservative using experimental plots as replicates in a blocked design. Nevertheless, we found no significant differences between sampling days and a highly significant effect of the vegetated areas, which underlines the strength of the patterns recorded.

Previous studies showed contrasting results related to the response of filter-feeding organisms to living in vegetated areas. While some studies showed a positive effect on growth and survival of clams (Peterson et al. 1984; Irlandi and Peterson 1991; Irlandi 1996; Peterson and Heck 2001) other authors found the opposite (Reusch and Williams 1999; Allen and Williams 2003). The former authors concluded that a combination of indirect factors promoted by the vegetation might be the responsible of such positive
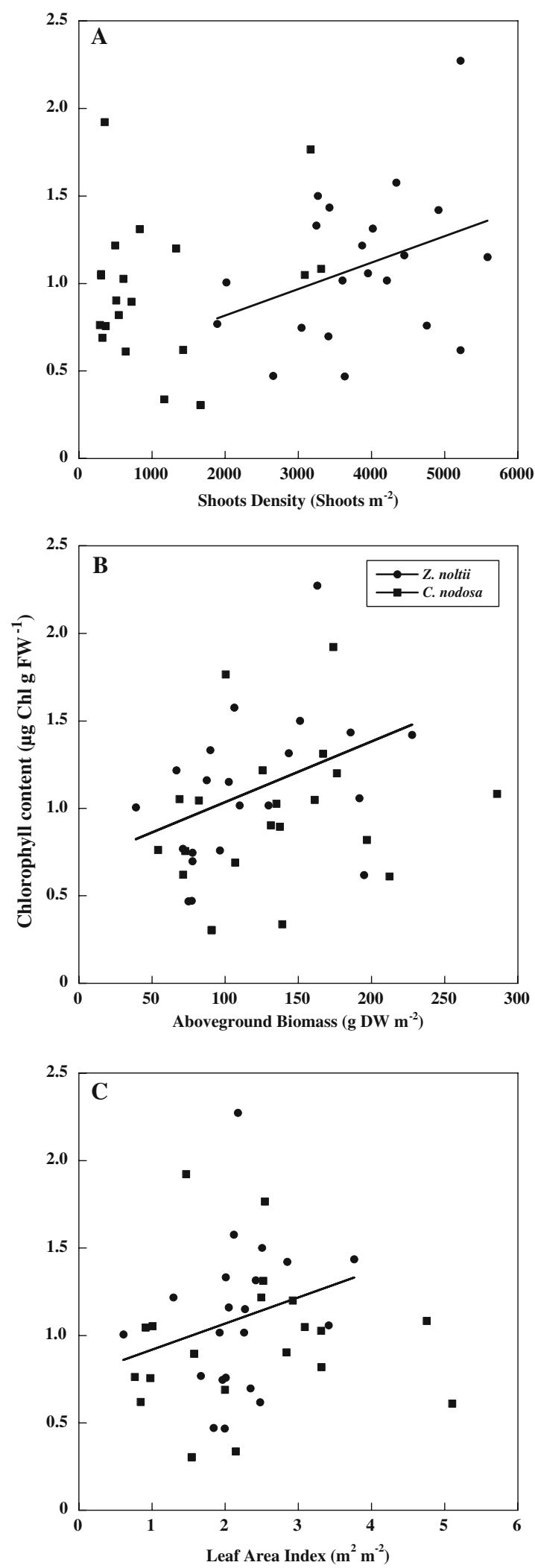

Fig. 2 Regression plots of the chlorophyll content on Cerastoderma edule and canopy properties of seagrasses. a Shoots density. b Aboveground Biomass. c Leaf area index (LAI). Statistical results of the regressions are showed in the "Results" section 
interactions: (a) alteration of the biological interactions (mainly predation-prey), (b) increment of the sediment stability and (c) changes on the food supply, while the later authors demonstrated that food limitation was the responsible for the recorded negative effects. Our study concluded that the food intake rate by filter-feeding $C$. edule was enhanced in those individuals feeding within the canopy, which may promote a higher growth rate and survival when the long-term is considered. Unfortunately, our study cannot explain whether the observed increment on the food intake rate was (a) due to an increment on the food availability within the canopy as recorded by Irlandi and Peterson (1991), as we only measured the food availability as $\mathrm{Chl} a$ in the water column outside the meadows (see site description methods), or (b) due to a relative reduction on filter-feeding activity of those cockles living on the nonvegetated areas (Irlandi and Peterson 1991; Irlandi 1996).

Reduction on the filter-feeding rate of benthic organisms living on bare sediment can be caused by a number of stresses. For example, an increment of predation disturbances may reduce the feeding time (Irlandi and Peterson 1991). Although C. edule within the canopy might be expected to profit from lower predation interference (Irlandi and Peterson 1991), this does not seem likely in our system, as recovery was over $95 \%$ for all experimental plots. Furthermore, the evaluation of siphon nipping and interference by predators in the absence of physical contact between predator and prey, as suggested by the same authors was not estimated in our experimental design. Alternatively, feeding time may be reduced by the continuous hitting of the siphons by particles transported on the water (Irlandi and Peterson 1991) or due to a high dynamic sedimentary which may imply a high cost of maintenance of the feeding position (Peterson and Beal 1989). The latter may seem a likely explanation, as the experiment was carried out in a relatively exposed area with strong hydrodynamics and high sedimentary dynamics (see Brun et al. 2005).

Individuals of $C$. edule that live within a canopy can only profit from a local reduction of the flow regime (i.e. higher sediment stability, lower disturbance on the feeding activity; Irlandi and Peterson 1991; Irlandi 1996; Fonseca and Fisher 1986), provided that the rate of food refreshment within the canopy is high enough to prevent food depletion. Food availability/depletion within the canopy will depend on the balance between the consumption and refreshment rate. Consumption is mainly dependent on the density, and filter feeding capacity and activity of the cockles, while food refreshment will depend of food availability on the surroundings water and in the flux of water through the canopy. It is obvious that food depletion within the seagrass meadows was not likely to occur in present study, regarding the high food intake rate of cockles present within the seagrass meadows. Also the lack of any negative correlations between the filter-feeding rate and canopy properties (shoots density, above biomass or LAI; Fig. 2) and the great increase in chlorophyll content between starved and experimental cockles (two to four times; Fig. 1) strongly suggests that in our experiment the food supply within both contrasting canopies was not limited.

Based on current findings, we speculate that some of the contradictory literature reports on the effect of vegetations on filter feeding might be explained by contrasting hydrodynamic conditions. In areas with relative strong hydrodynamics, as was the case in our study, food refreshment is high enough to prevent food depletion, whereas in more sheltered area this need not be the case. This would suggest that outcomes of ecosystem engineering by seagrass meadows on filter feeder performance has a conditional outcome, as has also been shown for other ecosystems (Norkko et al. 2006). Flume studies would offer an interesting approach for future studies to resolve these questions, since the use of a flume allows the manipulation of individual factors (e.g. hydrodynamic conditions, canopy properties, etc.) while maintaining a great control over the other controlling factors (predators, sediment stability, food availability in the water column, etc.). The conditional outcome of ecosystem engineering on biodiversity remains a research topic with much scope for future research.

Acknowledgments Brun FG is supported by an individual Marie Curie fellowship (MEIF-CT-2005-515071) and by a European Reintegration Grant (MERG-CT-2007-205675). E Cacabelos is supported by a post-doctoral grant from the Xunta de Galicia. This work was also supported by the Spanish Projects CTM2005-00395/MAR, the Dutch grants SBP/JK/2006-15 and SBP/JK/2007-32 and conducted as part of the EU funded network of excellence Marine Biodiversity and Ecosystem Functioning (MarBEF) responsive mode proposal D-4-4.2-2 "The role of native and/or invasive ecosystem engineers in explaining biodiversity". This is the NIOO publication number 4304.

Open Access This article is distributed under the terms of the Creative Commons Attribution Noncommercial License which permits any noncommercial use, distribution, and reproduction in any medium, provided the original author(s) and source are credited.

\section{References}

Abdelrhman MA (2003) Effect of eelgrass Zostera marina canopies on flow and transport. Mar Ecol Prog Ser 248:67-83

Allen BJ, Williams SL (2003) Native eelgrass Zostera marina controls growth and reproduction of an invasive mussel through food limitation. Mar Ecol Prog Ser 254:57-67

Beck MW, Heck KL Jr, Able KW, Childers DL, Eggleston DB, Gillanders BM, Halpern B, Hays CG, Hoshino K, Minello TJ, Orth RJ, Sheridan PF, Weinstein MP (2001) The identification, conservation, and management of estuarine and marine nurseries for fish and invertebrates. BioScience 51:633-641

Boström C, Bonsdorff E (2000) Zoobenthic community establishment and habitat complexity - the importance of seagrass shoot-density, 
morphology and physical disturbance for faunal recruitment. Mar Ecol Prog Ser 205:123-138

Bouma TJ, de Vries MB, Peralta G, Tanczos IC, van de Koppel J, Herman PMJ (2005) Trade-offs related to ecosystem engineering: A case study on stiffness of emerging macrophytes. Ecology 86:2187-2199

Bouma TJ, van Duren LA, Temmerman S, Claverie T, Blanco-Garcia A, Ysebaert T, Herman PMJ (2007) Spatial patterns in flow- and sedimentation within vegetation patches: comparing field, flume and hydrodynamic modelling experiments. Continental Shelf Res 27:1020-1045

Brun FG, Vergara JJ, Hernández I, Pérez-Lloréns JL (2005) Evidence for vertical growth in Zostera noltii Hornem. Bot Mar 48:446-450

Brun FG, Vergara JJ, Peralta G, García-Sánchez MP, Hernández I, Pérez-Lloréns JL (2006) Clonal building, simple growth rules and phylloclimate as key steps to develop functional-structural seagrass models. Mar Ecol Prog Ser 323:1-16

Costanza R, d'Arge R, Groot RD, Farber S, Grasso M, Hannon B, Limburg K, Naeem S, O’Neill RV, Paruelo J, Raskin RG, Sutton P, van der Belt M (1997) The value of the world's ecosystem services and natural capital. Nature 387:253-260

Duarte CM (1999) Seagrass ecology at the turn of the millennium: challenges for the new century. Aquat Bot 65:7-20

Eckman JE (1983) Hydrodynamic processes affecting benthic recruitment. Limnol Oceanogr 28:241-257

Emerson CW (1990) Influence of sediment disturbance and water flow on the growth of the soft-shell clam, Mya arenaria L. Can J Fish Aquat Sci 47:1655-1663

Fonseca MS, Fisher JS (1986) A comparison of canopy friction and sediment movement between four species of seagrass with reference to their ecology and restoration. Mar Ecol Prog Ser 29:15-22

Fonseca MS, Fisher JS, Zieman JC, Thayer GW (1982) Influence of the seagrass, Zostera marina L., on current flow. Estuar Coast Shelf S 15:351-364

Folkard AM (2005) Hydrodynamics of model Posidonia oceanica patches in shallow water. Limnol Oceanogr 50(5):1592-1600

Fréchette M, Bourget E (1985) Energy flow between the pelagic and benthic zones: factors controlling particulate organic matter available to an intertidal mussel bed. Can J Fish Aquat Sci 42:11581165

Gambi MC, Nowell ARM, Jumars PA (1990) flume observations on flow dynamics in Zostera marina (eelgrass) beds. Mar Ecol Progr Ser 61:159-169

Heck KL Jr, Nadeau DA, Thomas R (1997) The nursery role of seagrass beds. Gulf Mexico Sci 1997:50-54

Heck KL Jr, Orth RJ, Hays CG (2003) Critical evaluation of the nursery role hypothesis for seagrass meadows. Mar Ecol Progr Ser 253:123-136

Hummel H (1985) Food intake of Macoma balthica (Mollusca) in relation to seasonal changes in its potential food on a tidal flat in the Dutch Wadden Sea. Neth J Sea Res 19(1):52-76

Irlandi EA, Peterson CH (1991) Modification of animal habitat by large plants: mechanisms by which seagrasses influence clam growth. Oecologia 87:307-318

Irlandi EA (1996) The effects of seagrass patch size and energy regime on growth of a suspension-feeding bivalve. J Mar Res 54:161-185
Jeffrey SW, Mantoura RFC, Wright (eds) (1997) Phytoplankton pigments in oceanography: guidelines to modern methods. SCORUNESCO Monographs on Oceanographic Methodology, Paris

Jones CG, Lawton JH, Shachak M (1994) Organisms as ecosystem engineers. Oikos 69:373-386

Kagan BA, Alvarez O, Izquierdo A (2005) Weak wind-wave/tide interaction over fixed and moveable bottoms: a formulation and some preliminary results. Cont Shelf Res 25(7-8):753-773

Kamermans P (1993) Food limitation in cockles (Cerastoderma edule (L): Influences of location on tidal flat and of nearby presence of mussel beds. Neth J Sea Res 31:71-81

Koch EW, Gust G (1999) Water flow in tide- and wave-dominated beds of the seagrass Thalassia testudinum. Mar Ecol Prog Ser 184:63-72

Koch EW (2001) Beyond light: physical, geological, and geochemical parameters as possible submersed aquatic vegetation habitat requirements. Estuaries 24:1-17

Larkum AWD, Orth RJ, Duarte CM (eds) (2006a) Seagrasses: biology, ecology and conservation. Springer, The Netherlands, 691pp

Larkum AWD, Drew EA, Ralph PJ (2006b) Photosynthesis and metabolism in seagrasses at the cellular level. In: Larkum AWD, Orth R, Duarte CM (eds) Seagrasses: biology, ecology and conservation. Springer, The Netherlands, pp 323-345

Morris EP, Peralta G, Brun FG, Duren L, van Bruma TJ, Pérez-Lloréns JL (2008) Interaction between hydrodynamics and seagrass canopy structure: spatially explicit affects on ammonium uptake rates. Limnol Oceanogr 53(4):1531-1539

Nelson WG, Bonsdorff E (1990) Fish predation and habitat complexity: Are complexity thresholds real? J Exp Mar Biol Ecol 141:183-194

Norkko A, Hewitt JE, Thrush SF, Funnell GA (2006) Conditional outcomes of facilitation by a habitat-modifying subtidal bivalve. Ecology 87:226-234

Peterson CH, Beal BF (1989) Bivalve growth and higher order interactions: importance of density, site, and time. Ecology 70:1390 1404

Peterson BJ, Heck KL (2001) Positive interactions between suspension-feeding bivalves and seagrass - a facultative mutualism. Mar Ecol Prog Ser 213:143-155

Peterson CH, Summerson HC, Duncan PB (1984) The influence of seagrass cover on population structure and individual growth rate of a suspension-feeding bivalve, Mercenaria mercenaria. J Mar Res 42:123-138

Pile AJ, Lipcius RN, Montfrans J, van Orth RJ (1996) Density-dependent settler-recruit-juvenile relationships in blue crabs. Ecol Monogr 66:277-300

Reusch TBH, Williams SL (1998) Variable responses of native eelgrass Zostera marina to a non-indigenous bivalve Musculista senhousia. Oecologia 113(3):428-441

Reusch TBH, Williams SL (1999) Macrophyte canopy structure and the success of an invasive marine bivalve. Oikos 84(3):398-416

Strickland JD, Parsons TR (1968) A practical handbook of seawater analysis. Fish Res Bd Can Bull 167

Verduin JJ, Backhaus JO (2000) Dynamics of plant-flow interactions for the seagrass Amphibolis antarctica: Field observations and model simulations. Estuar Coast Shelf S 50:185-204

Zar JH (1984) Biostatistical analysis. Prentice-Hall, New York 